\title{
Defying Stereotypes
}

\section{The Cold War and Its Strategic Lessons to Learn from North Korea's Example}

\author{
Vassily B. Kashin
}

\begin{abstract}
In this article the author probes into how the Democratic People's Republic of Korea and its political regime managed to survive in defiance of internal economic problems and external political, economic and military pressures it experienced since 1991. Comparison of the available statistics illustrating North Korea's economic and internal political situation, as well as pressure methods and tactics used on a smaller scale against a far stronger country, the Soviet Union, during the Cold War, allows for taking a fresh look at the effectiveness of foreign policy instruments the United States created during its confrontation with the Soviet Union. Consolidation of the country's ruling elite amid foreign pressures and exposure to external threats are identified as factors that play the decisive role in determining the outcome of the standoff. The effectiveness of pressure strategies apparently depends on this factor.
\end{abstract}

Key words: DPRK, Cold War, China, elites, isolation, technologies, post-Soviet development, modernization, political transformation.

Vassily B. Kashin, Ph.D. in Political Science, is a senior research fellow at the Center for Comprehensive European and International Studies at the National Research UniversityHigher School of Economics. He is also a leading research fellow at the Institute of the Russian Far East.

SPIN РИНЦ: 3480-3664

ORCID: 0000-0001-9283-4528

Researcher ID: A-9102-2017

vkashin@hse.ru

DOI: $10.31278 / 1810-6374-2018-16-2-177-192$

VOL. 16 • No. 2 • APRIL - JUNE • 2018 
Torth Korea's post-Soviet history is a valuable socio-political experiment. Over the past few decades North Korea definitely broadened our knowledge of an individual small state's abilities to pursue a long-term policy of confrontation with a number of major world powers without leaning on an alliance with other great powers.

The implementation of such a policy was possible to a certain extent thanks to North Korea's internal political stability, which looks especially surprising, if one bears in mind that the country's economy and living standards are way behind those of its neighbors (according to the International Monetary Fund and Hyundai Institute, North Korea's nominal per capita GDP was a tiny $3.6 \%$ of South Korea's).

Locked among hostile (at best, wary-neutral) states, North Korea for nearly three decades not only persevered to stabilize the domestic political and internal economic situation. The North Korean regime also made significant progress in addressing issues which it considered crucial for its survival in the long term. The country achieved considerable success in the development of military and dual-purpose technologies, launched independent production of sophisticated missile weapons and, by most estimates, succeeded in creating the first usable nuclear weapons.

North Korea's ability to successfully mobilize a variety of resources to achieve results in certain areas of development is well seen in the fact that Pyongyang managed to get ahead of Seoul in the space race by orbiting its first satellite on December 2012 (SPACE.com, 2012). South Korea managed to put its satellite into orbit only at the end of January 2013 (Kramer, 2013) even though it boasted immeasurably larger financial resources, access to modern technologies and vast opportunities for cooperation with some of the world's leading space powers.

The question what keeps political systems stable in the face of social revolutions and the attempts to find sensible answers to it through a broad comparison of different countries' experiences have long attracted the attention of many researchers. An important example of such analysis is found in James DeFronzo's book called "Revolution 
and Revolutionary Movements" (DeFronzo, 2015), which delves into and compares the circumstances of revolutionary regime changes from Russia in the early 20th century to the collapse of socialist governments in Eastern Europe, the Asian revolutions, the events in Venezuela in the 21 st century, etc.

North Korea is absent from this list of extinct political regimes, although by many standards, such as economic development, the people's standard of living, and the level of political and public institutions, it was in a far inferior position and experienced stronger external pressures. The very existence of North Korea refutes the mass media's prevailing viewpoint on how viable such totalitarian regimes are.

DeFronzo paid attention to such revolution-generating factors as mass discontent, the split of elites, catchy ideas shared by a significant part of society, crisis of governance and favorable external conditions. Many students of Korean affairs have undertaken attempts to apply this approach to the North Korean realities to arrive at the conclusion that practically none of the conditions DeFronzo mentioned (except for discontent with the economic situation) were anywhere in sight (Lankov, 2017).

North Korea prompts to take a fresh look at the last decades of the Cold War and the circumstances of the Soviet Union's demise. The collapse of the USSR and the Soviet bloc states was a result of internal processes in these countries, the credit for which partly goes to the U.S. for its "correct" policies of undermining the stability of communist regimes. The collapse of the USSR was the universal excuse for many Cold War tools, such as deterrence, economic and technological sanctions, propaganda war, etc.

A correct assessment of the relevant experience and corresponding tools is necessary not for another round of painful historical truthseeking, but for understanding what made the political instruments the confronting parties employed so effective.

The Cold War ended with the Maltese summit in December 1989 and no-winners-no-losers cooperation rhetoric. The chaotic disintegration of the socialist system and the USSR itself in 1990-1991 changed the retrospective perception of Cold War results. 
After George H.W. Bush's memorable statement in January 1992 ("By the grace of God, America won the Cold War") the opinion of the Cold War as a prolonged and senseless confrontation that came to an end with the necessary compromise was brushed aside. The Cold War's ending was proclaimed as the United States' triumphal victory. So great that victory was that those claiming paternity were too numerous to count. Those people wrote numerous books to generate whole branches of knowledge devoted to studying victorious strategies. These strategies still live on, although attempts to put the Cold War arsenal to use in the post-Soviet period yielded disappointing results more often than not.

\section{NORTH KOREA: CONTRARY TO EXPECTATIONS}

North Korea represents a chemically pure example of all conceivable Cold War strategies being used against a seemingly vulnerable target. And an equally pure example of their utter failure. From the economic and foreign policy viewpoint, the DPRK was in the worst situation among the socialist states that had managed to endure the USSR's collapse. Unlike China and Vietnam, North Korea by the time of the Soviet Union's disintegration had a rather clumsy energy-intensive and noncompetitive economy. Given its natural conditions and socialist methods in agriculture, the country was unable to feed itself (Kim, 1998). Nor was it self-sufficient in energy. The attempts taken as early as the 1980s to create an export-oriented industry (light industry) were not crowned with success. The export of military equipment grew step by step, but it was way below the demand for foreign currency. The rigid centralized economic management system was an exact replica of the Soviet command and administrative model polished to the point of absurdity.

After the collapse of the Soviet Union the North Korean leaders for a long time were in no hurry to launch reforms. Experiments with very limited and inconsistent transformations started only in the 2000s. But relatively more rapid changes followed only after Kim Jong-un's rise to power in late 2011.

The North Korean leaders were not very competent in such 
matters as ideology and propaganda, which remained primitive and often ludicrous. In the meantime, starting from a certain moment Pyongyang could no longer afford to keep the country reclusive any more. During the hunger of the 1990s hundreds of thousands fled to China. In the early 2000s North Koreans in North-East China numbered 100,000-300,000 (Charny, 2003). Many of them eventually returned home. In the 2000s cheap DVD-players, South Korean films and pop culture started pouring in from abroad.

Tens of thousands of North Koreans work abroad and the government encourages the export of labor. According to estimates by the Database Center for North Korean Human Rights (NKDB), the number of North Korean workers abroad could be as big as 60,000 (Snyder, 2015). Actually, their number is apparently greater. At least the NKDB statistics for Russia look incomplete. These days North Koreans have an idea of what the lifestyle of their neighbors in the region is like. This has had no visible effects on the regime's stability yet, though.

Throughout its history, North Korea remained unrecognized by such countries as the United States, Japan, and South Korea, which left no chance for developing normal economic relations with them. After the 2006 nuclear tests the sanctions began to escalate. A series of unilateral sanctions to isolate North Korea from the U.S. and the U.S. financial system was launched by the United States in 2000 and has been significantly expanded since 2008 . Unilateral U.S. sanctions were supplemented by UN Security Council restrictions. After several rounds of tightening the sanctions (the most serious ones were in 2009, 2013, 2016, and 2017) North Korea was disconnected from the global financial system. Import and export of military products are prohibited. The supplies of basic raw materials (coal, seafood, nonferrous and rare-earth metals, textiles, etc.) are limited (OFAC, 2016).

Meanwhile, these goods constitute the bulk of North Korea's export. As of 2015, coal briquettes (34\%) were the most significant item of North Korean export, followed by ore mining products, textiles, bio resources, and products of machine-building and electronics (OEC, n.d.). Slowly but surely the situation evolved towards economic blockade. 
Nevertheless, starting from 2006 North Korea has seen a noticeable economic upturn and fast progress in military production. The economic recovery was achieved through a series of fairly obvious decisions to partially dismantle socialist management methods in agriculture, the services, and industry, and also through targeted investments in infrastructure. The negative consequences of sanctions began to manifest themselves only towards the end of 2017, when pressures came very close to total blockade, with China and Russia joining in.

While remaining in complete isolation, the North Korean militaryindustrial complex showed rapid progress in creating new types of missile weapons. Some technologies are original and domestically engineered. Tangible progress is observed outside the military industry. North Korea independently produces rolling stock for its railways and metro lines, surface urban transport vehicles and various models of cars and trucks. It also makes complex types of industrial equipment (for example, $\mathrm{CNC}$ machine tools and laser 3D scanners) and equipment for thermo-electric and hydroelectric power stations.

Sanctions have failed to prevent North Korea from launching the production of smartphones and tablets with its own OS on the Android platform and creating a fairly well-developed infrastructure of its own equivalent of the worldwide web, separated from the Internet. It has its own search engines, e-commerce portals, social networks, multiplayer online games, etc. Many other countries that are not under sanctions have been trying to pursue proactive industrial policies, too, but they still do not produce anything like this.

However successful, North Korea still remains the poorest country in Northeast Asia with low living standards. Yet the authorities keep the situation under control and feel quite confident.

To a certain extent this confidence rests upon mighty security services, but this is not the only explanation. North Korea is imbued with corruption and has a huge shadow economy. In a situation like this, the system could not survive only by means of repression. It lives on and develops because a considerable part of the population is interested in its existence. This interest is the main and only distinction between the surviving Communist regimes and the USSR 
and its Eastern European satellites, where such models collapsed in the blink of an eye.

As Andrei Lankov (2013) noted earlier, "It will be extremely difficult for the North Korean nomenklatura to desist from the ideology they have lost faith in long ago, but at the same time to retain a considerable share of real power as entrepreneurs who have privatized state enterprises, or as even democratic politicians, as it happened in the USSR and in a number of socialist countries. The North Korean nomenklatura perfectly understands that nothing good is in store for it in a future integrated state... Moreover, some senior North Korean officials fear the winners may resort to repression."

\section{UPPER CLASSES CAPABLE, LOWER CLASSES AGREEABLE?}

The ineradicable innate defect of Soviet-style Socialism is that the "top" $10 \%-15 \%$ of the population (involved in decision-making) are gradually losing interest in preserving the socialist system. Having eliminated the internal opposition and gained a firm foothold "at the top," the socialist elite becomes increasingly concerned about its own security and suddenly realizes that the system works against its interests. High-responsibility jobs involving strenuous effort, great risks and stress and requiring top-notch education do not provide proper remuneration. Within a Soviet-type socialist system, the huge social capital, accumulated by these people, can be converted into comfort and consumption only to an insignificant extent. The contrast between their own living standards and those of the elite in other countries is demoralizing. The dismantling of the socialist system from above becomes inevitable.

In some cases, it occurs as uncontrollable collapse, while in others, it proceeds as stage-by-stage systemic reconfiguration, leaving the basis intact and preserving the fundamental opportunity to restore at least some of the settings to default again.

The chaotic dismantling of the Soviet system between the end of the Cold War (the Maltese summit of 1989) and late 1991 occurred before the eyes of an amazed world and even against the backdrop of attempts by some former opponents of the USSR in the Cold War 
to prevent this process and support the collapsing Soviet state. One can recall the well-known statement U.S. President George H.W. Bush made in Kiev on August 1, 1991, when he suggested preserving a new Soviet Union reformed in accordance with Mikhail Gorbachev's plans (Hunt, 1991).

In contrast to this, China started along the road of transforming its economy in the late 1970s while being engaged in a tough military standoff with the USSR, and it embarked on a new stage of reforms in the early 1990s still facing serious external pressures and criticism over the 1989 Tiananmen Square events.

The surviving Communist regimes (let us call them so for convenience, although their ideological mutation and revision of many canons is obvious practically in almost all cases, while the ideological basis is still there) are different from one another in many respects but one: the awareness of the tight link between the survival of the political system, on the one hand, and the physical security and well-being of the elite, on the other. All other parameters affecting the stability of the socialist system matter little, if at all. Governance mistakes in the context of the command economy and the absence of market selfregulation mechanisms periodically cause severe crises. But if the authoritarian state has the willpower to carry on in conformity with socialist slogans, it is capable of promptly coping with these crises, taking advantage of its ability to instantly focus resources on priority projects and guidelines.

In North Korea one can see an example of the elites' obvious interest in the survival of their inherently socialist state. To some extent this is so due to the extremely repressive nature historically intrinsic to the North Korean model. The country has a fairly archaic society with large strata of people who are either disfranchised or, on the contrary, privileged on account of class origin and revolutionary merits of their ancestors, and with a large penitentiary system and widespread use of capital punishment. Besides, people's memories of recent famine are still fresh.

Back in its early days the North Korean regime started creating a sophisticated system of ascribed social status, now known as Songbun. 
The system establishes 51 categories of the population according to the family's social origin and personal merits. The castes are distributed among three "groups" by the degree of loyalty to the regime. Affiliation with a certain category plays an important role in getting access to social security benefits, education, and career promotion. Although this system has undergone certain evolution and been eased somewhat, the individual's background still plays a crucial role in the North Koreans' lives and career prospects (Collins, 2012).

External pressures aggravate the situation. Legally, from South Korea's point of view, all North Korean institutions and government agencies are criminal by nature and liable to elimination. In accordance with South Korea's Law on National Security, North Korea is an "antistate organization," in other words, an entity that has misappropriated the ruling status and created its own system of government. The law establishes serious penalties for being a member of or for providing assistance to an anti-state organization (NSL 1948/1988, Ch2). Although the law is now complemented with amendments, reservations and exceptions and its administration in recent decades was much milder than it used to be during the Cold War, it remains a major factor of pressure on the North Korean elite.

Alongside the legal aspects, the North Korean elite must also take into consideration the highest level of North Korea's "demonization" in the world media and the existence of large groups of repressed or disfranchised citizens in its own country. In the event of hypothetical takeover by the South (using Germany's template, for example), not only the top brass, but also the middle and lower tiers of the North Korean party and government machinery, the special services and army officers will have to brace for losing their social status and rights and, with a high degree of probability, for poverty, repression and extrajudicial persecution and violence. Pressures by the United States, which proved its aggressiveness in Libya and Iraq, are another factor that makes the North Korean elite mobilize itself and take the necessary decisions to conduct reforms and redistribute resources.

Similar situations are found in other communist states that have successfully transformed themselves. For example, China at the 
beginning of reforms remained a country that had just emerged from the bloody Cultural Revolution, famine and wholesale repression. The Communist Party's hypothetical loss of power would have inevitably triggered large-scale violence and reprisals against the regime's functionaries. Deng Xiaoping-led second-generation leaders were well aware of that.

China's solution to the problem of keeping the social system stable was confined to setting in motion a mechanism of stage-by-stage market reforms that opened up fast enrichment opportunities before the old elite and its entourage. The leading positions in Chinese businesses still belong to relatives or proxies of Communist Party functionaries. In the process of reforms, the elite acquired unmistakably dynastic features, with property and power often pooled within one family by means of concluding carefully planned marriages.

The caste of "princelings," in other words, relatives of senior Chinese Communist Party officials who have now taken the leading positions in the national economy, began to take shape at early stages of reforms, thus giving birth to a specific Chinese brand of "bureaucratic capitalism." For example, senior posts in the top management of newly-created state corporations, such as China International Trust and Investment Corporation (CITIC), established in 1979, belonged first to Wang Jun, son of China's former Vice-President Wang Zhen, and then to Kong Dan, son of the former head of the CCP Central Committee's Investigation Department, Kong Yuan. Other lucrative positions for attracting the "princelings" at the early stage of reforms were created in the army-related foreign trade corporation Poly Technologies and the investment company Kanghua Development Corporation (Ho, 2012).

Certainly, reforms and economic growth improved the population's welfare, but the riches accumulated in the hands of the select few are stunning. According to Hurun Report, China in 2016 outperformed the U.S. as to the number of dollar billionaires (594 against 535), although the two countries are incomparable in terms of wealth and the level of development. In China, there are still fewer millionaires than in the United States (3.6 million against 6.9 
million), but perhaps this is due to identification problems, because many in China prefer to keep quiet about their fortunes. And in any case, the number of millionaires is growing very fast (Frank, 2016, Hurun Report, 2017).

The goal of the Chinese state is to preserve the foundations of the old system. For example, in his report to the XIX Congress of the Chinese Communist Party, the CCP's General Secretary and China's President Xi Jinping said public enterprises should become "bigger and stronger." The government considers them as a kind of "national champions" that accumulate huge state resources for supporting international expansion. Great attention is paid to modernizing the Communist Party's bodies and enhancing its leading role.

The same socialist methods are employed for mobilizing and concentrating resources along key guidelines under the personal supervision of top managers to handle other important tasks, such as eliminating the technological lagging behind the West.

Eastern Europe's total dismantling of socialism is a stark contrast to the Chinese scenario of its transformation. It entailed more or less complete sale of public property, ultra-liberal economic policies, an ostentatious U-turn away from the past, and prosecution of some members of the old-time elite who constituted its secluded minority (for example, state security service officers). At the same time, a greater part of the former elite managed to use its social capital in the new conditions to the full; it served as the basis of the political class up to the natural change of generations in the 2010s. Such changes became possible because the old elite felt no risk of being victimized, the countries in question were small and their level of development relatively high, and the West provided support.

The choice between gradual transformation of socialism and its rapid dismantling depended not on economic factors, but entirely on the interests of the $10-15 \%$ of the population that constituted the elite of the "old regime" - their security and welfare. Fear was the key factor that prompted unambiguous choice in favor of gradual transformation.

The Russian way of development may be considered intermediate. Having started along the path leading towards wholesale dismantling 
of the old system, Russia realized very soon that, on the one hand, the external pressures had resumed (NATO's expansion, Western attempts to eliminate Russian influence in the post-Soviet space), and that the situation inside the country was close to going out of control, on the other. As a result, Moscow turned onto a track very much similar to the one the transformation-minded regimes had opted for earlier. While some liberal reforms went on, the role of the public sector in the economy was consolidated and control of civic life tightened (although in this respect Russia cannot compare to China or Vietnam).

The lifetime of a Soviet-type socialist state is essentially determined by one parameter, namely, how fast the elite's loyalty dwindles to naught. Everything else does not matter. North Korea's experience shows that the socialist system is able to withstand the highest level of external economic, political and even military pressures, provided the authorities' morale remains high.

\section{DELETERIOUS DELUSION}

The strategies to which success in the Cold War was attributed had nothing to do with the actual circumstances surrounding the collapse of the USSR. Moreover, many of them actually helped the Soviet system stay afloat by scaring and mobilizing the leadership in Moscow. Such methods as financial and economic sanctions, military intimidation and propaganda demonization are examples of such hopelessly losing strategies. The attempts to use them for undermining authoritarian regimes in recent decades invariably brought about disappointing results, even if the target under attack was obviously weak. For example, extremely harsh sanctions against Saddam Hussein's Iraq, including severe restrictions on both import and export, attained nothing. Even after 13 years of sanctions the regime remained so strong that nobody even dared say it could be toppled in a special operation or limited strike. It required a full-scale U.S. invasion in 2003. The effects for the United States itself and the Middle East were disastrous.

Technological sanctions are capable of producing only very limited results: however scarce the available resources, a socialist state is capable of concentrating gigantic efforts in several priority areas of science and 
engineering, where it is likely to achieve an impressive result. North Korea's achievements are not an exception. The Soviet Union's militaryindustrial base inherited from the Russian Empire was modest, to say the least, but throughout its history it systematically reduced the lag in military technologies used by the leading Western countries. Having started with the simple copying of Western tanks, aircraft and ships, the Soviet Union in its last days achieved approximate parity in many respects. And in some cases, it gained superiority. Mao's povertystricken China managed to develop and produce entirely on its own a whole range of ballistic missiles for delivering nuclear warheads, while wealthy and industrialized Britain turned out unable to cope with a task like this.

It goes without saying that lower priority industries that enjoy little attention from the top leadership are doomed to stagnate regardless of the external factors, such as Western sanctions. A Soviet factory that produced the same car model for 30 years was doing so not because it lacked access to the wonders of the Western engineering thought, but only because such a state of things was good enough for its management and the automotive industry in general: the production target was invariably met with no great efforts exerted. And nobody cared that in the meantime a design bureau next door was working on cutting-edge futuristic projects, like solar or hydrogen vehicles (such models were actually tested in the Soviet Union in the 1970s-1980s). In other words, progressing paralysis of governance and management, and not the ostensible incompatibility of socialism or totalitarianism with innovations was the root cause of the problem.

Actually, all the United States could do during the Cold War was to hold back Soviet expansion until the socialist mechanism broke down due to certain design flaws. Even though it had far greater resources at its disposal, the United States showed disastrous inefficiency in its efforts to contain the Soviet Union: the Soviet sphere of influence kept growing until the late 1970s, when the socialist system's internal corrosion already became irreversible.

North Korea is nurturing no expansionist ambitions. Its goal is to guarantee the regime's survival by means of acquiring nuclear 
weapons and forcing the United States into a direct dialogue on ways of normalizing relations. The first part of the plan has been successfully implemented despite firm resistance from Washington and from almost all other major world powers that support the U.S. Now we are slated to see the implementation of the second part of the plan while U.S. experts and politicians indulge in "how-come-it-happened-thisway" debate and panic.

The post-Cold War delusion that the U.S.-led West employed a successful strategy to win a victory over Soviet Union is not harmless at all. This delusion has already bred a number of absurd strategies that caused a string of disasters, including Iraq and, to some extent, Yugoslavia and Syria. Certain risks still remain, and this list may grow longer to include another disaster of the kind, a Korean one, which would also be the worst-ever. In Russia, this delusion nourished revanchist sentiment and nostalgia for the Soviet Union. After all, to mourn for an empire that perished in battle is much easier than for an empire that disgracefully sank into oblivion. And in the United States this deeply ingrained myth tempts decision-makers to employ the same invariably abortive political tools over and over again on the pretext that they played the key role in the Cold War, while in reality they did not.

\section{References}

Bush G.H.W., 1992. State of The Union Address. Speeches by U.S. Presidents. [online] Available at: <stateoftheunionaddress.org/category/george-hw-bush> [Accessed 22 April 2018]

Charny, J., 2003. North Korean refugees in China. [pdf] Testimony to the Senate Committee for Foreign relations. Available at: <www.foreign.senate.gov/imo/ media/doc/CharnyTestimony031104.pdf> [Accessed 22 April 2018].

Collins, R., 2012. Songbun: North Korea's Social Classification System. The Committee for Human Rights in North Korea [pdf] Available at: <www.hrnk. org/uploads/pdfs/HRNK_Songbun_Web.pdf> [Accessed 23 April 2018]. 
DeFronzo J., 2015. Revolutions and revolutionary movements. 5th ed. Boulder: Westview Press.

Frank R., 2016. China has more billionaires than U.S.: Report. CNBC [online] Available at: <www.cnbc.com/2016/02/24/china-has-more-billionaires-thanus-report.html> [Accessed 23 April 2018].

Ho Wing-Chung, 2012. The rise of bureaucratic bourgeoisie and factional politics in China. Journal of Contemporary Asia, 42(3), pp.514-521.

Hunt, T., 1991. "Stick with Gorbachev," Bush tells Republics. Chicago SunTimes [online] Available at: <www.highbeam.com/doc/1P2-4066079.html> [Accessed 23 April 2018].

Hurun Report, 2017. Hurun Research Institute [online] Available at: $<w w w . h u-$ run.net/EN/Article/Details?num=5A320E03FD31> [Accessed 23 April 2018].

Kim Cheon-koo, 2014. North Korea's per capita GDP and comparison with South Korea. Economic Review, 14-11 (582), March 14, [online] Available at: $<$ www.koreafocus.or.kr/design2/layout/content_print.asp?group_id=105314> [Accessed 21 April 2018].

Kim Woon-Keun, 1998. Agricultural situation in North Korea. [pdf] Korea Rural Economic Institute. Available at: <www.fftc.agnet.org/htmlarea_file/library/20110726131553/eb475.pdf> [accessed 22 April 2018].

Kramer, M., 2013. South Korea launches rocket in 1st space success. [online] Available at: <www.space.com/19553-south-korea-launches-naro-rocket-satellite.html $>$ [accessed 21 April 2018].

Lankov A., 2013. TSugtsvang Phen'iana. Pochemu Severnaia Koreia ne poĭdët kităskim putëm. Rossiia $v$ Global'nŏ Politike. 11(2) [online] Available at: $<$ globalaffairs.ru/number/Tcugtcvang-Pkhenyana-15962> [Accessed 23 April 2018]

Lankov A., 2017. Is revolution possible in North Korea? [online] Available at: $<$ www.nknews.org/2017/03/is-revolution-possible-in-north-korea/> [accessed 22 April 2018] 
NSL, 1948/1988. South Korea's National Security Law [online] Available at: > www.hartford-hwp.com/archives/55a/205.html> [Accessed 23 April 2018]. OEC, n.d. MIT Observatory of Economic Complexity Data [online] Available at: <atlas.media.mit.edu/en/profile/country/prk/> [Accessed 22 April 2018]

OFAC, Office for Foreign Assets Control, 2016. North Korea Sanctions Program. Washington: U.S. Department of Treasury [pdf] Available at: <www. treasury.gov/resource-center/sanctions/Programs/Documents/nkorea.pdf $>$ [accessed 22 April 2018].

Snyder, S., 2015. North Korea’s latest export: Labor. Forbes, May 22, 2015 [online] Available at: <www.forbes.com/sites/scottasnyder/2015/05/22/north-koreas-latest-export-labor/\#2ebef1ae785d $>$ [accessed 22 April 2018].

SPACE.com staffs, 2012. North Korea Successfully launches Satellite, [online] Available at: <www.space.com/18867-north-korea-rocket-launch-satellite. html $>$ [accessed 21 April 2018]. 